\title{
Reproductive control in South Africa
}

Carol E. Kaufman

Follow this and additional works at: https://knowledgecommons.popcouncil.org/departments_sbsr-pgy

Part of the Demography, Population, and Ecology Commons, Family, Life Course, and Society Commons, and the International Public Health Commons How does access to this work benefit you? Let us know!

\section{Recommended Citation}

Kaufman, Carol E. 1997. "Reproductive control in South Africa," Policy Research Division Working Paper no. 97. New York: Population Council. 


\section{Reproductive Control in South Africa}

Carol E. Kaufman

1997 No. 97 


\title{
Reproductive Control in South Africa
}

\author{
Carol E. Kaufman
}

Carol E. Kaufman is a Berelson Postdoctoral Fellow, Policy Research Division, Population Council. A previous version of this paper was presented at the 199596 Sawyer Seminar, Social Movements and Social Change in A Globalizing World, Advanced Study Center, The International Institute, University of Michigan. 


\begin{abstract}
The controversial state-sponsored family planning program officially began in South Africa in 1974. Although the government did not implement the program on a racial basis, the program was widely believed to be linked with white fears of growing black numbers, and was attacked by detractors as a program of social and political control. In spite of the hostile environment, black women's use of services steadily increased. Using historical and anthropological evidence, this paper delineates the links between the social and political context of racial domination and individual fertility behavior. It argues that the quantitative success of the family planning program is rooted in profound social and economic shifts conditioning reproductive authority and fertility decisionmaking. The analysis traces tensions over reproductive control within and across three different arenas: the evolution of national politics of population; the transformation of gender relations within a racially discriminatory society; and the proscriptions of everyday life for black women. State policies of racial segregation and influx control, ethnic "homeland" politics, and male labor migration transformed opportunities and constraints for black women and men, and altered local and household expectations of childbearing. Women came to manage their own fertility as they increasingly found themselves in precarious social and economic circumstances.
\end{abstract}

This material may not be reproduced in any form without written permission from the author. 
The state-sponsored family planning program officially began in South Africa in 1974 in the midst of rising black unemployment, rapid black urbanization, and increasing militancy against the regime. The government promoted family planning services as a measure to improve the health of women and their children; it also acknowledged the program was a way to place a check on the high growth rate burdening limited resources. The government did not implement the program on a racial basis, services were provided free to any woman who sought them; however, the links between the family planning program and white fears of growing black numbers were widely acknowledged. Reports of forced sterilization and coerced contraceptive use furthered the suspicions of the program as a manifestation of another apartheid policy aimed at controlling the lives of blacks. Controversy quickly ensued. Accusations were lodged against family planning as a dubious program of control with genocidal undertones while supporters waxed rhetorical about an imminent population explosion that demanded immediate and decisive action by the government. Although the political climate surrounding fertility control had been at best hostile prior to the early 1990s, the program had been successful in several dimensions. Use of family planning services had increased continuously since 1974 (see Figure 1); current use of modern contraceptives had achieved a remarkably high level, estimated to have reached 44 percent for African women ${ }^{1}$ in the late 1980s; and the total fertility rates (TFR) across all population groups continued to decline (see Figure 2) for Africans in the late 1980s, the TFR was estimated to have dropped to 4.6 children per woman of reproductive age, the lowest in sub-Saharan Africa at that time. ${ }^{2}$ Whereas politics evidently did not cause a stagnation in family planning use, the numbers documenting the trends toward lowered fertility beg the question of how the larger sociopolitical context of racial domination inhibited or encouraged reproductive control. How 
Figure 1 Average number of women protected per month, South Africa, 1969-93

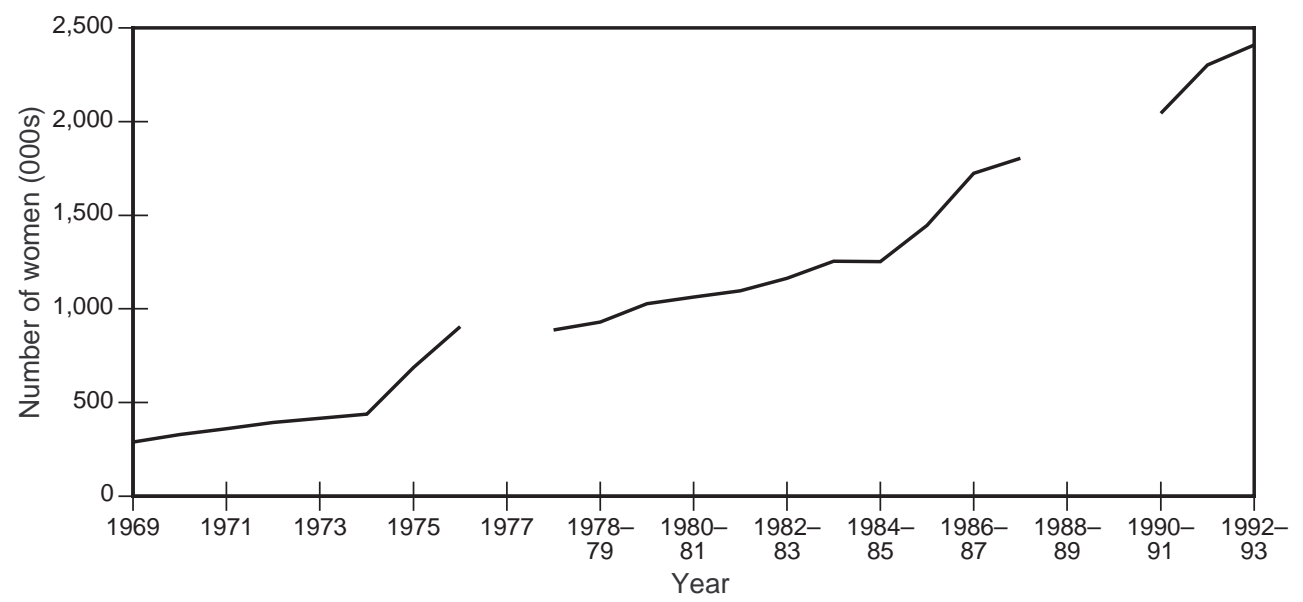

Source: Department of Health, Republic of South Africa, Annual Report, 1969-93.

can it be that family planning was at once not politically viable yet highly successful?

Academic isolation and the politicization of family planning in the country severely curtailed investigation into reproductive dynamics. The few researchers that did venture into South African population policy emphasized the state's role, outlining the suspect nature of the family planning program as a component of the white government's agenda to control the nonwhite population (Brown, 1983 and 1987; Chimere-Dan, 1993; Klugman, 1993). While state-focused approaches are useful as a critique of the program and of the government under which it operated, they offer few insights into why so many women sought the program's services. A different approach is taken by Caldwell and Caldwell (1993). They construct their argument not in terms of the state's manipulation of population policy, but around fertility and contraceptive prevalence patterns in the country. They assert 
Figure 2 Estimated total fertility rate by population group, South Africa, 1945-89

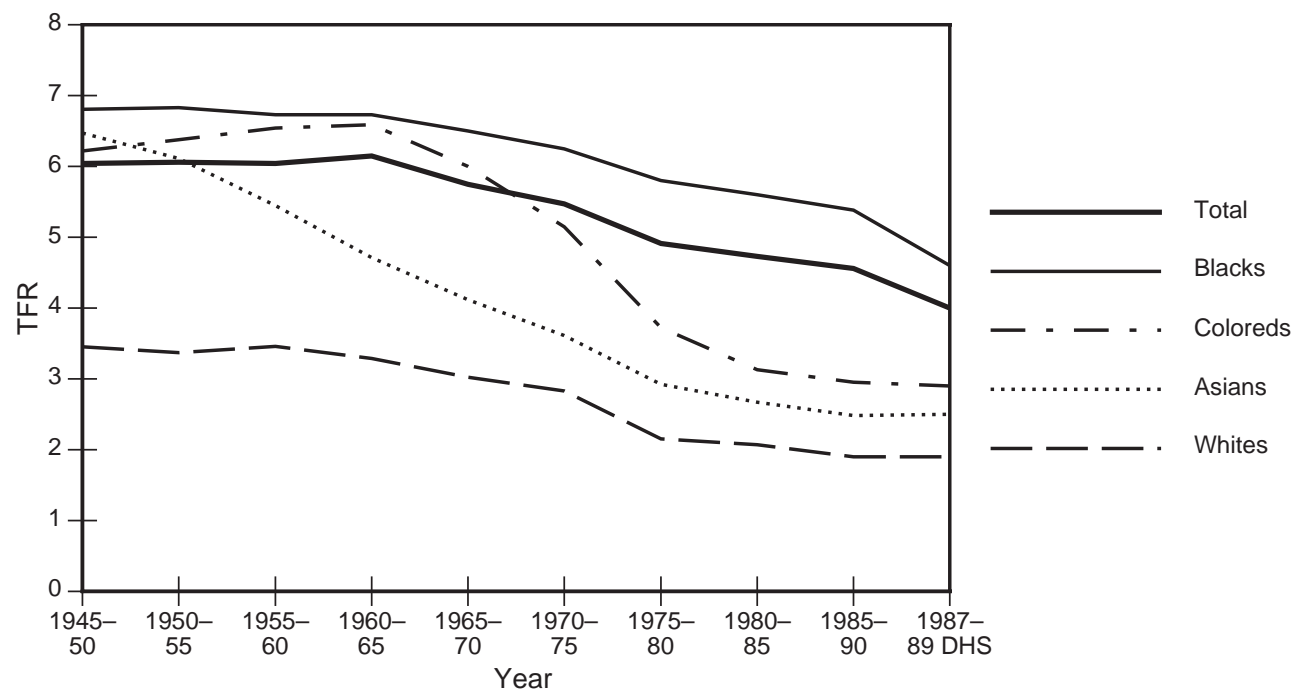

Source: Du Plessis et al. (1991).

that given the level of socioeconomic development in the country and the level of financing enjoyed by the national family planning program, South Africa's fertility is not as low, and contraceptive use levels are not as high, especially among blacks, as might be expected. Caldwell and Caldwell are concerned with why women and their partners have not controlled their fertility more than they have. They suggest three factors that may have acted to inhibit fertility decline: (1) the pronatalist practices or beliefs specific to the indigenous cultures of the area; (2) suspicion of the family planning program; and (3) the disincentives to lower fertility inherent in apartheid policies. Their review of the literature illustrating these points offers tantalizing insights into some of the pressures and expectations of childbearing in South Africa, but it skirts the issue of why so many have opted for fewer children. Indeed, the issues Caldwell and Caldwell proffer as explanations for what 
they interpret as a laggard decline in fertility could easily be inverted: Given the adverse political conditions or an adherence to pronatalist traditional practices, why has fertility declined as much as it has?

Whether the patterns of reproductive behavior have reached levels above or below expectation are two sides of a larger question: What have been the tensions produced by the political climate surrounding fertility dynamics in South Africa, and how has the manifestation of those tensions in women's lives affected their decision to control their fertility? This paper proposes that there have been dramatic shifts in social and economic opportunities and constraints in women's lives, and that with these shifts, personal, familial, and community expectations of childbearing also have undergone profound change. The vigorous but politically compromised family planning program facilitated women's control over their fertility in the context of that uncertainty.

This paper delineates the relationship between political context and individual fertility behavior in South Africa. The first part of the argument presents the history of reproductive control in the country, a history proscribed by racially based population policies on the one hand, and a transformation of gender relationships on the other. The second part considers the confluence of these forces at the community level, where the politics of suspicion toward family planning were manifest. The program was perceived by many blacks as a symbol of racial domination, and these attitudes were supported by widespread reports of abuse, misinformation, and coercion, compounding the social and personal cost of contraceptive use. The third section focuses on reproductive control from women's perspective. It details the way women managed their productive and reproductive lives in the con- 
text of gendered tensions over childbearing and rearing, community and familial expectations of their fertility, and social and economic uncertainty. The paper concludes by considering recent developments in family planning and reproductive health and prospects for further transformation. The arguments presented below are primarily concerned with the intersection of the politics of population policies and the responses by and consequences for Africans, who constitute about 75 percent of the population. The variations in effect of these policies across other racial groups is equally interesting but beyond the scope of this paper.

\section{Race and Population in South Africa: Historical Roots of Policy and Programs}

The history of reproductive control and family planning in South Africa is tightly bound with the policies and laws that entrenched social and economic inequality by race. Family planning services were available as early as the 1930s in South Africa through beneficient welfare societies, but these were intended to cater to poor whites; services at that time were considered appropriate only for the "improvement" of the white race, not as a means to curb population growth. Instead, early population concerns rested squarely with population distribution: "superfluous natives," those not working for white industry or households, should be prohibited from entering "white" cities. Greater black presence in cities was of deep concern to the white population and may have served to expedite more aggressive reserve laws. In 1936, the Representation of Natives Act designated that 13 percent of the land in South Africa be set aside for Africans. ${ }^{3}$ This important piece of 
legislation, on which homeland policy in future years would be built, appeared to resolve simultaneously two pressing dimensions of the "native question": "Excess Africans" could be removed from white cities to "their own" land; and these African areas then also could become centers for cheap available labor, quite literally reserves of labor to be channeled as necessary to white farms, industry, or mines (Kaufman, 1996).

The victory of the Nationalist Party on the apartheid platform in 1948 did not initially mark a departure from these population priorities. Both legislation and public rhetoric promoted large, healthy white families, encouraged white immigration, and discouraged black migration to the cities, except under stringent conditions of employment (Brown, 1983 and 1987; Chimere-Dan, 1993). The apartheid government's primary concern was still centered on the distribution of Africans as opposed to their overall numbers. This sentiment is perhaps best captured by H.F. Verwoerd, considered the architect of apartheid, when he spoke to Parliament in 1965 (cited in Caldwell, 1970: 67): "I want to state very clearly that, whilst I am in favour of a reduction of the number of Bantu in our white areas, I need not be concerned that their presence, or even an increase in their numbers, accounts an actual violation of our policy. In terms of our policy even increasing numbers still constitute no danger." Such obstinacy was not long-lived, and increasing population size did become a concern. In the meantime, however, the reserve policy was elaborated and entrenched under the rubric of "separate development." This ideology, underwritten by racial and ethnic separatism and a daunting labor migration system, became a key element in the politics of population issues, molding the parameters of reproductive control and fertility decisionmaking at the political and personal levels. 
Separate development grew out of a political concern to appease the segregationist and assimilationist positions on the "native question." The anthropological notion of culture found its way into the political vernacular as a legitimizing concept framing separatist policies although acknowledging the potential of Africans to develop (Dubow, 1987). Instead of focusing on racial differences and the attendant physical distinctions thought to correspond to those categories, the government imposed ethnic denominations, ostensibly based on home language, with an intention to group culturally homogenous people. Drawing on the idea that "tribes" were uniquely different and culturally distinct, the strategy of separate development, formalized during the 1960s, was built on the premise that racial and ethnic groups should develop independently and at their own pace. The government designated areas for each group in which to reside; the Republic of South Africa (RSA) was designated as the white area and segregated residential areas within it were set aside for whites, coloreds, and Indians, and for properly documented blacks. Ten ethnic homelands, or bantustans, were set aside for Africans. These were no longer simply black reserves, but "tribal" areas that could one day become independent countries. ${ }^{4}$ All Africans were assigned to their "appropriate" homeland (whether or not they had any kin ties there), and only documented workers were allowed as "guests" in white areas. Separate development not only furthered the pre-1948 reserve and labor policies, but seemed to provide an answer to the problem of a growing and less pliable black population: It fostered ethnic divisions within the black population; it released the Republic of South Africa from its responsibility for Africans because homeland residents would come to forfeit South African citizenship; and it placed whites in a more favorable position in the numbers 
game because they would not be compared numerically to a whole African population, but to ethnic subpopulations. The ideology also precipitated urban removal programs that grew in intensity throughout the 1960s and 1970s through which many Africans from "black spots" were resettled with or without their consent to the homelands (Platzky and Walker, 1985).

Separate development was the embodiment of the white public desire to rid white areas of "superfluous" blacks, but even as it was implemented, the realization soon developed that cordoning them off in homelands was not sufficient. White faith began to falter that ethnic homelands would somehow stem the growth of a burgeoning African population, diffuse the political potential of their numbers, or reduce the drain on (white) resources. As reflected in official census numbers, Figures 3 and 4 show that, not surprisingly, the urban black population continued to grow as did the overall population. ${ }^{5}$ Although the homelands did not contain African population growth in urban or rural areas, as a strategy for controlling and regulating African mobility and labor, the homeland system was, in fact, fairly successful, with two important consequences for fertility control: First, the prolonged absence of men placed severe constraints on family building, reproductive decisionmaking, and family maintenance as women were left to fend for themselves and their children. Second, the set of rights accorded homelands as a part of their progress toward independence also had a direct impact on family planning service provision. Both of these points are detailed in later sections.

As concern over population issues moved beyond urban white-black ratios to include overall differential population growth trajectories, the government reluctantly moved toward a national family planning program. For many years, the government insisted officially that Africans were not sufficiently developed to accept family planning or that family planning was not 
Figure 3 Urban population by race, South Africa, 1904-91
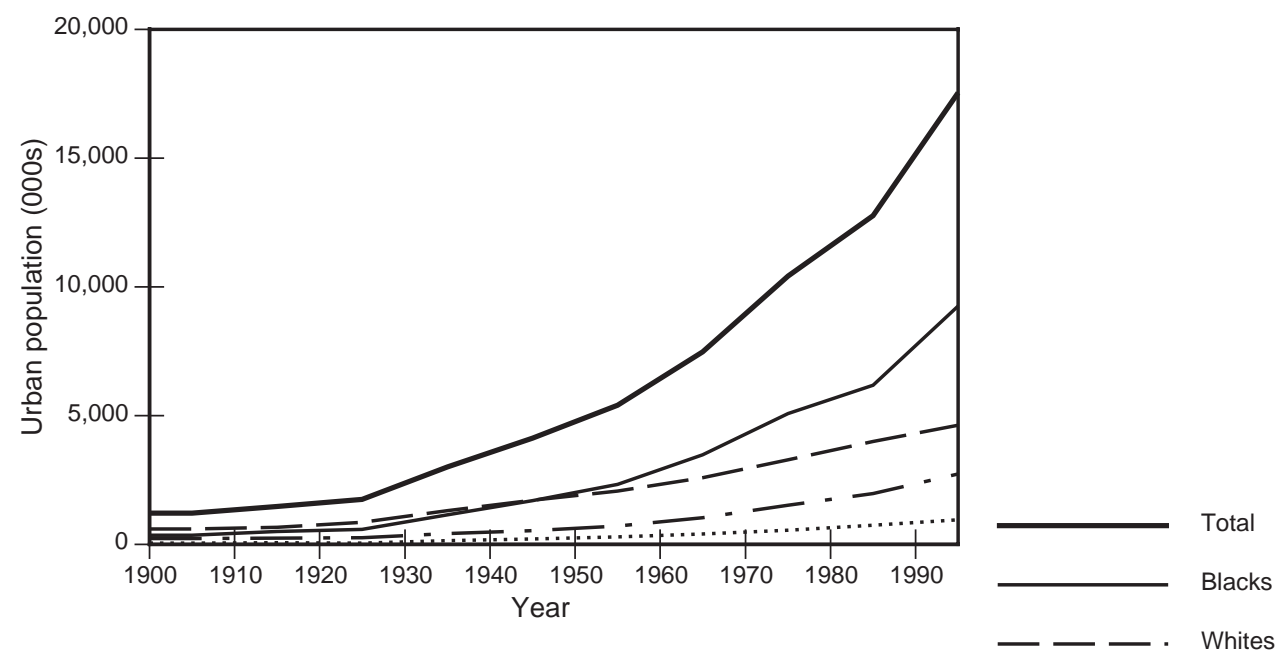

Figure 4 Population by race, South Africa, 1904-91
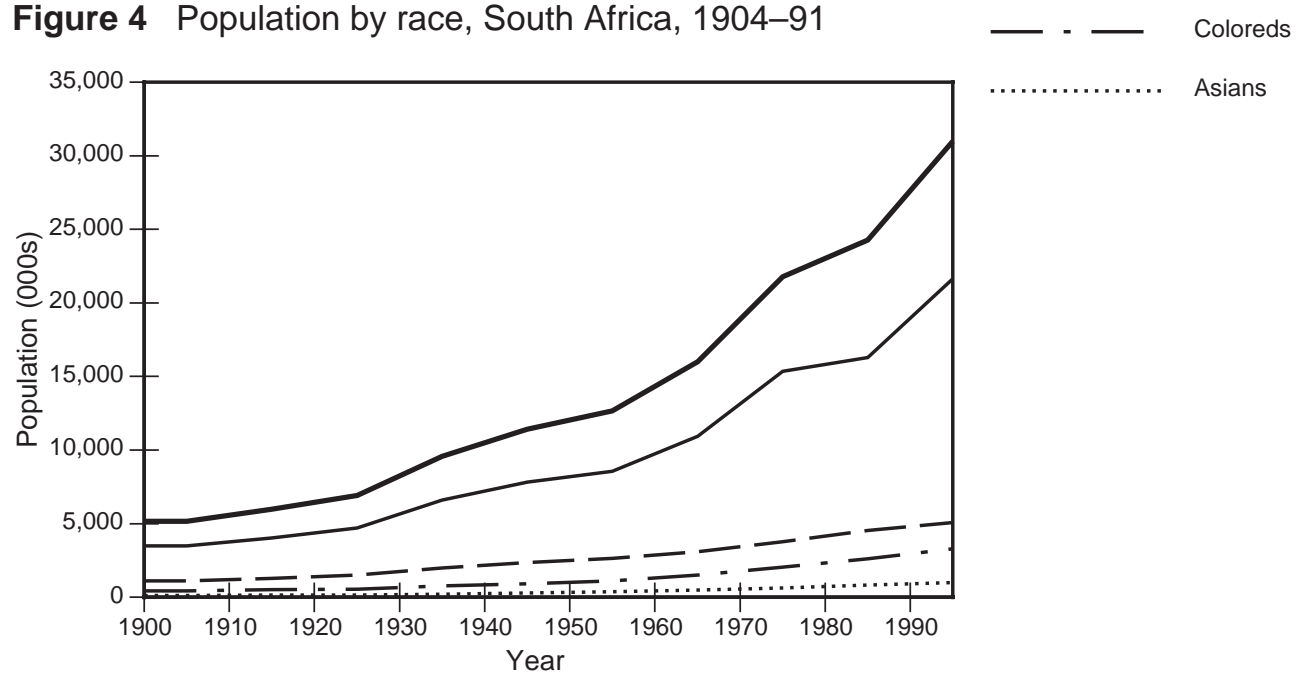

Note: Census years are 1904, 1911, 1921, 1936, 1946, 1956, 1960, 1970, 1980, and 1991.

Source: Central Statistical Service (1993).

culturally acceptable. Unofficially, it wished to avoid the political outrage that family planning, easily interpreted as a racially motivated plan, might engender. This concern was not ill-founded, as policymakers had in hand 
numerous examples of prominent leaders provoking controversy. In 1967, Minister of Bantu Affairs Botha appealed to every white couple to have an extra child for the nation (an appeal known as the "Baby for Botha campaign"). His appeal produced little change in the white birth rate, but observers reported that nonwhite attendance at family planning clinics dropped sharply in the months following the statement (Caldwell, 1970). In 1962, H.F. Verwoerd, in his oft-quoted speech at the granting of self-governance to the Transkei, emphasized the demographic basis of apartheid (in ChimereDan, 1993: 32): "If the one multi-racial state were to become a federally constituted state ... or a unitary state [that is, one-person, one vote] and at the same time be truly democratic and in harmony with the spirit of the times, it would inexorably lead to Bantu domination. Because in the long run numbers must tell." In the context of increased national and international condemnation of apartheid policies, these public declarations of a numbers game by political leaders further stymied the government's ambition to implement a family planning program. However, political events of the 1960s acted as a strong counterbalance to political sensitivity. The black consciousness movement had taken root, a new wave of black unrest swept over the country in the aftermath of the Sharpeville massacre in 1960, and the winds of change were blowing through the rest of the continent, bringing a shift in power from white colonial hands to black nationalist ones. Heightened white fears of being swamped by blacks exerted pressure on the government to do something about the situation that was thought to threaten the stability and economic progress of the nation.

International events in population and family planning at that time provided a convenient legitimizing frame for South Africa's reticent steps to- 
ward implementing a national program. A number of articles and books on imminent global doom appeared at this time, such as Paul Ehrlich's The Population Bomb (1968) and Georg Borgstrom's The Hungry Planet (1965) and demonstrated that the population explosion was not just a South African problem, it was a world problem. Furthermore, as in other parts of the world, the most explosively growing populations were nonwhite (see, for example, South American Medical Journal, 1970). Foreboding population figures from progovernment South African intellectuals were publicized widely in the press, and the inadequacy of voluntary organizations to provide family planning services nationally was becoming increasingly evident (Sadie, 1970; van Rensburg, 1972). International attention to population issues also legitimized national family planning programs and proffered examples on successful implementation (Harkavy, 1995; Sharpless, 1994), while results of localized demographic studies in the late 1960s showed relatively high levels of demand among nonwhite urban women and indicated that a program might be well received (Mostert and Engelbrecht, 1972; Mostert, 1972; Mostert and van Eeden, 1972; and Mostert and du Plessis, 1972). On 1 February, 1974, at the opening of the parliamentary session, Prime Minister B.J. Vorster announced at the end of his address that "the Government associates itself with the idea of a World Population Year in 1974 and is accepting its responsibility in this connection by developing a country-wide family-planning programme" (Hansard's, 1974: 13).

The main developments and history of the family planning program have been discussed elsewhere (Lucas, 1992; Caldwell and Caldwell, 1993; Kaufman, 1996), and only a brief overview is provided here. The national family planning program began as a single-purpose service, and, at an early 
point, nurses were permitted to deliver services without physicians' authorization (Stockton, 1990). The program underwent tremendous growth in the number of clinics, trained personnel, and in resource allocation (Brown, 1987; Lucas, 1992). In the 1992-93 fiscal year, for example, more than 65,000 service points were in operation, including all fixed and mobile clinic sites (Department of Health, 1992). Although the program was vigorous and wellequipped, it went through a number of transformation, mainly to address or to avoid criticism. The maneuvering, however, did not diminish the strong demographic rationale that underpinned — and plagued - the program from its inception (Kaufman, 1996).

In the early 1980s, the President's Council commissioned an extensive report on demographic trends in South Africa (Republic of South Africa, 1983). As a result of that report, the Population and Development Program (PDP), the population policy arm of the government, was initiated in 1984 charged with the responsibility of popularizing the consequences of high population growth in South Africa and promoting the small family ideal. The objectives of the program, as outlined by the Minister of Health and Welfare, were (1) to stabilize a population of 80 million by the end of the next century; (2) to accelerate social and economic development in order to achieve parity in the development levels of the different population groups by the middle of the next century; (3) to achieve a total fertility rate of no more than 2.1 children per woman of reproductive age and thus target the sectors of the population growing fastest; and (4) to ensure an "orderly spatial distribution" of the population through coordinated involvement in health, education, and economic programs, and urban and rural development schemes (Hansard's, 1984: 6,529; Department of Health, 1984). As the emissary for 
population policy of the apartheid government, however, the PDP did not have the popular acceptance of the targeted communities. Also, it was not vested with the authority to realize its objectives, in spite of the high profile the government accorded it at its commencement. The inappropriate nature of much of the educational work of the PDP, suspected links to security forces, draconian demographic ideology, and an institutionalized powerlessness to effect development brought heavy and widespread criticism (van Rensburg, 1994; Klugman, 1991, 1993 and 1994; see also van Zuydam, 1994, for dissent within the PDP).

Ironically, the very populations meeting the definition of "targeted communities" in need of family planning services (that is, low socioeconomic level, generally rural, with high fertility rates) were precisely those out of reach: African women in the so-called homelands. Under the policy of separate development, ethnic homelands would move toward independence from the white Republic of South Africa, and thus would have to grapple with their own population pressures. Control over health services, including family planning services, was a part of the plan for the independence for homelands. As various homelands declared themselves "territories," they were granted self-governing rights within their borders, and responsibility for health services was duly handed over to them (Department of Health, 1973 and 1975). Neither the family planning program nor the PDP of the (white) Republic could provide services or conduct educational activities in the homelands unless officially invited to do so. Although little was known about exact fertility patterns in the homelands, the idea was widely accepted that levels were high and, importantly, so was the demand for services. To avoid compromising the "sovereign rights" of these areas, 
the program set up mobile clinic sites and services in places most easily accessible to homeland women. Clinics sometimes provided services "across the street" from homelands so that women could walk over the border, or sometimes clinics were organized at shops frequented by black women when they traveled to the Republic (little commercial activity transpired in homeland areas; market activity was another domain controlled under apartheid) (Stockton, 1995).

The government's family planning program, in tandem with the PDP, served millions of women, most of them African, even in a hostile political context. The services it provided undoubtedly facilitated declines in fertility and increased contraceptive use, especially among blacks. However, the implementation of the national family planning program did not initiate the demand for reproductive control or even necessarily sustain it. Shifts in expectations of and opportunities for women that directly influenced the numbers of children they bore had begun well before the start of national family planning. Once the program began, women made the decision to use contraceptives in spite of familial or community opposition, not solely because of educational materials or accessibility of clinics, but because circumstances in their lives compelled them to do so.

\section{Gender, Race, and Reproductive Control: Transformation and Tension}

Mason (1987) asserts that fertility control cannot be considered a strictly individual decision; it is a process that requires authority, and that authority is socially derived. The locus of authority over women underwent a rapid shift in the present century, a continuing process, but one that has been largely 
ignored until recently (Cock, 1988; Seidman, 1993). Research on women in South Africa has tended to focus on the purposes women's subordination served for capitalism (Bozzoli, 1983). Indeed, this relationship has been well documented, especially for migrant laborers and their families. Briefly, black women were left on the reserves charged with the care of children and the family's sustenance. This arrangement enabled the capitalist establishment to maintain a low-paid migrant labor force, because wages did not have to provide for a whole family, and the reproductive and productive functions of home subsidized the laborer who, therefore, required a smaller living wage (see, especially, Wolpe, 1972). Focus on the relationship between capital and gender, as argued by Bozzoli, deflected analysis of relations of power and domination between men and women. Bozzoli's point is particularly salient to an examination of fertility control. The state apparatus designed to control labor and African mobility and residence was a system that exerted differential forces on the lives of men and women and their families. The insertion of these policies into their lives, in combination with existent patterns of authority and control, have shaped the boundaries of decisionmaking concerning fertility.

The long history of migrant labor in South Africa has structured social relations at every level of society. Walker (1990: 169), writing on the impact of the development of migrant labor on women, argues that this labor system "open[ed] up opportunities for increased personal autonomy and mobility at an individual level while radically undermining the security previously accorded women in pre-colonial society." As with segregation policy, labor migration did not commence with apartheid, but was developed and extended at various junctures throughout South African history. 
The transformation in authority over women and their fertility were derived in large part from the twists and turns of the expanding labor migration and pass-law systems.

The streams of migrant labor shifted considerably in their demographic composition over time. The early phase of migration, prior to the turn of the century, generally was comprised of young men whose income provided a flow of wealth to the homestead in the form of cattle, hoes, and guns. Women's work was central to homestead maintenance and was not significantly affected by the absence of young men. Productive and reproductive activities of women and migrant youth were under the authority of traditional chiefs and elders during this period who procured tributes from wage labor and lobola (brideprice) payments (Walker, 1990). By 1930, the system of migrant labor had become a dominant force in the lives of all who lived in South Africa, even in the rural periphery. By this time, however, the agricultural capacity of the reserves was no longer able to sustain its population, and men of all ages and women were leaving the reserves, which constituted an alarming threat to the authority (and income) of chiefs. The flow of Africans from the reserves also worried white administrators of the still nascent migrant-labor system who seemed unable to channel appropriately the increased numbers of men leaving the reserves, and who viewed women's presence in urban areas as unnecessary and even dangerous. Chiefs and administrators collaborated in a variety of ways to control female mobility (expressed as "rampant immorality") using pass laws, restrictions to transport, and "repatriation" of "runaway" wives (Walker, 1990: 181).

The confluence and distortion of African and white forms of social organization became increasingly evident. Men of both systems desired control over women. For African elders, this meant the continuation of brideprice 
practices and female agricultural production. Colonials agreed that women should stay in the reserves to preserve the "tribal way of life"; however, administrators were far more concerned with the centrality of women's contributions in subsidizing the wages of black workers. The cultural argument they used glossed over deep contradictions imposed by the labor policy; even while colonials were concerned with "tribal customs" in the control of women, they were not concerned with the devastation the migrant-labor system caused to tribal life by the prolonged absences of men from their families and communities. Furthermore, in spite of the colonial concern with tradition, the laws formalized at this time reflected obvious assumptions of a conjugal family defined in western terms. Laws on adultery and divorce figured prominently in new legislation, and marked the dilution of elders' authority over women and a strengthening of husbands' rights (Walker, 1990).

With the inauguration of the Nationalist Party in 1948, the government pursued more repressive strategies to control Africans. Posel (1991) persuasively warns, however, that the policies formulated thereafter were not a part of a grand design, but rather a product of internal state tensions and liaisons and were essentially ambiguous and contradictory. The practical effects of the implemented policies on the lives of the black population, however, were not so ambiguous. Section 10 of the 1951 Native Laws Amendment Bill stipulated that a native should not remain in an urban area for more than 72 hours unless he was born there or resided there for at least 15 years, has worked continuously for one employer for ten years, or "unless such a native is the wife, unmarried daughter or son under the age at which he would become liable for the payment of general tax ...." The gendered language of the Bill is intentional. Conceding to widespread black protest, the legislators agreed not to require women to carry passes (Posel, 1991: 102). 
In 1952, the year the Native Laws Bill was enacted, 164,324 blacks were "endorsed out" of white urban areas on pass violations. The number increased yearly thereafter, reaching an annual average of 541,500 during the peak years of 1970-75 (Wilson and Ramphele, 1989: 206). ${ }^{6}$ To accomplish such a feat, the Native Affairs Department and the police and security force underwent tremendous expansion. Large sums of money were dedicated to maintaining a growing police force and to upholding the bureaucratic structures necessary to process the many pass violations in accordance with the law. The result was a daunting escalation of police harassment of and interference with blacks, mostly men, in their daily lives. Random checks, questioning, humiliation, and continual fear of their precarious status in the cities became a part of everyday life.

The late 1950s saw an upsurge in African resistance to apartheid policies. In spite of this, or perhaps because of it, by 1959 pass-law legislation was extended to women. Also, Posel (1991) argues that the protests catalyzed a significant shift in ideology in the application of policy occurred. Specifically, it was during this period that idea of separate development was formalized, and much harsher categories of "nonproductive" labor were defined to facilitate relocation of Africans. They included:

[T] he aged, unfit, widows, women with dependent children and also families who do not qualify under the provisions of the Bantu (Urban Areas) Act ... for family accommodation in the European urban areas ... professional Bantu such as doctors, attorneys, agents, traders, industrialists, etc. Such persons are not regarded as essential for the European labour market .... Normally they are well-to-do Bantu and by settling these people with buying power in the homelands, a great con- 
tribution can be made to the development of those territories (Posel, 1991: 234).

However, many Africans remained legally and illegally in the so-called white areas of South Africa in townships and squatter areas in the hope of better access to jobs, education, and social services. Others remained on white farms and in other rural areas partly because semifeudal employment practices kept them in these places (James, 1988).

The dramatic shift in content and the intensity of enforcement of pass laws instituted by the National Party took a heavy toll economically and socially on black women and men (Posel, 1991). Blacks in the urban areas and townships who were held on some type of infraction were allowed to pay an admission-of-guilt fine, often an unaffordable penalty for black workers earning meager wages. The alternative to the fine was a jail sentence that extended the period of absence of men from their families (and women as well when they came under the law's jurisdiction), placing an added burden of providing for families on women (Posel, 1991). In the reserves, most women by this time had become economically dependent upon remittances from urban migrant labor for at least part of their subsistence. Workers "endorsed out" posed doubly debilitating burdens: They no longer contributed to homestead income, and they further diluted scant resources upon their return to the homeland household (Posel, 1991).

From women's point of view, the migrant-labor system, predominated by men, represented both opportunities and hardships. A woman left on a reserve often assumed a great deal of economic and productive responsibility for the family in her husbands' absence and was often less willing to submit to her husbands' wishes upon his return (Sharp and Spiegel, 1990). 
However, she had to contend with the uncertainty of his wages and the possibility that he might not return. Before the collapse of agricultural viability in rural areas in the early part of this century, men sent money home as a type of investment. With the deterioration of the reserve lands resulting from overworked soil and increased population, however, men were more likely to use money for consumption, rather than investment, making male wages an even less reliable economic resource (Moodie and Ndatshe, 1992). Abandoned wives, landless women, or women otherwise escaping from an oppressive domestic situation traveled to mine areas, often illegally, in the hope of reasserting rights to support from partners, attracting male liaisons to procure improved living conditions, or to engage in beer-brewing, prostitution, or other economic activities for which migrants provided a market. Other women turned to nonmining urban areas to pursue what they felt had to be a more promising life.

Thus far, South Africa's "native" policies have been considered in terms of their impact on the nature or locus of control over women's fertility or on the larger social and economic context within which fertility dynamics transpired. Although historical information is fragmentary, the evidence suggests that control over women fundamentally shifted from elders, to elders under supervision of colonial powers, and finally to husbands. During the 1950s, however, a husband's control over a woman's sexuality and fertility became much less clear and much less stable. Many have observed rise in divorce, desertion, and extramarital relationships as a result of the stresses of migrant labor (Longmore, 1959; WHO, 1983; Posel, 1991; Romero-Daza, 1994). As changes in patterns of marital union, family structures and economy continued, a commensurate shift from men to women in responsibility for family building also occurred. 
Longmore (1959: 51-60), observing life in a Johannesburg township from 1950-57, noted that "[urban males] were evading the responsibilities of fatherhood by way of the loose union, irregularly formed giving rise to the temporary family" and that it was not unusual for a woman to change husbands frequently, and often while also providing care for two, three, and four children. She also observed that women in urban settings no longer adhered to the patriarchal authority of their former rural homes. She described them as wiser and more adept at negotiating with men to maintain themselves and their children. Another source of insight into this changing dynamic comes from Bozzoli and Nkotsoe (1991). Their book is a compilation of life histories collected from older women residing in Phokeng, a small town in the Western Transvaal. The women's remembrances of their family lives in townships or urban areas of Johannesburg during the 1930s reveal incipient changes in relationships between men and women. Bozzoli (1991: 134) asserts that women had already "shown willfulness and independence from patriarchal control at home." Constructing a household for themselves and their children in the city was a central factor in targeting the employment sectors in which they would seek work, and sometimes in deciding which relationships they would maintain. For example, one woman reported that after the death of her first husband, she did not want to marry because she could not be sure a new husband would support, or allow her to support, her children: "If I had another husband, who would have paid for [the children's] schooling? I hated a man like a prison. I wanted to look after my children." Another woman sent her children back to her mother to rear, which allowed her to work at slightly more lucrative jobs and to send money home to her children. Other women withdrew from formal-sector jobs, preferring the flexibility of informal work required for proper child care (Bozzoli and 
Nkotsoe, 1991). Having children and maintaining a home for them was central to women's lives. Their ability to do so, however, was highly proscribed by the forces of racially based employment and housing restrictions. Initially, in the circumstances of deteriorating economic possibilities in rural areas and unreliable social and economic relationships with men, women had little choice but to assert themselves within a system that offered them few opportunities. Nonetheless, women increasingly were better prepared and more willing to negotiate relationships and employment to suit their needs.

Opportunities and responsibilities were apportioned differentially to black men and women in South Africa. The response to those differences over time in the context of racially based labor and segregation policies of South Africa comprised an integral component to the social process of fertility control. Women took increased responsibility for the number of children they bore, and their decision to do so warrants further investigation. Before turning to issues of reproductive control from the perspective of women, however, the specific political context of family planning as a means of fertility control is discussed. Indeed, the opinions found in black communities toward family planning, coupled with the heavy-handedness for which the program was renowned, acted as a mediating force, an additional layer of political and social assertion shaping women's reproductive decisions.

\section{Uses and Abuses of Family Planning Under}

\section{APARTHEID}

Black community leaders have been tremendously influential in mobilizing or suspending action among their constituencies on a wide variety of issues. Their opinions about family planning had the potential of creating a conducive or hostile environment for reproductive decisionmaking. Such 
leaders have almost always been male. The complexity of gender relations in South Africa, varying considerably across regions and in urban and rural settings and coupled with high levels of censorship in a repressive system, makes a detailed assessment of family planning at the community level difficult. Media reports, however, indicate a high level of hostility to family planning, both because of the political numbers game implied by the program, and because many saw fertility control as an affront to (male) authority and counter to the African way of life. Relatively little expression was given to concern for the health or well-being of women and their children or for the role of men in the maintenance of their families.

In 1982, for example, the African Communist, a paper issued from London by the South African Communist Party, ran an article entitled "Family planning in South Africa - a kind of genocide" :

The so-called national family planning programme is being used to perpetuate White domination and the oppression and exploitation of the Black majority.... In the South African context family planning tramples on rights of the oppressed Black majority and the hostility with which the oppressed majority have reacted to this policy is a direct result of the historical experience of racist White minority rule which has systematically robbed them of the land and the liberty and is now intent on restricting their right to reproduce themselves. The people's rejection of population control is part of their strategy for self-preservation. (Hansard's, 1983: 283-284).

In 1988, Stephen Sihebe, the KwaZulu minister of welfare and pensions, stated that every extra African child was a boost for freedom, and that even if big families had to do without the bare necessities of life, in the name 
of the liberation struggle, sacrifices must be made (SAIRR, 1988). The effect of such exhortations are unknown. In Cape Town in 1985, a noticeable, albeit temporary, drop in clinic attendance occurred subsequent to one political call for more black children (Cape Times, 1985), and in Port Elizabeth in 1986, clinics were forced to close because of threats and intimidation (Weekend Post, 1986). However, the political call for "freedom babies," "people's rejection of population control," or a statement criticizing the 1983 report on demographics on the basis that "it is against the culture of black people to have fewer children" (Hansard's, 1983: 623) seemed to have more to do with political positioning than with the constraints of women's lives. Male political leaders may not have acknowledged the risks or benefits of family planning to women, but women in leadership positions in the black community also voiced concerns with the racial motivations of the program. In 1987, the director of community affairs for the Urban Foundation, Deborah Mabietsa, claimed that the government was using birth control to ensure white control (SAIRR, 1988), and Sister Bernard Ncube, president of the Federation of Transvaal Women, stated that contraception is a "safe way of murdering a nation" (The Star, 1986), a sentiment seconded by Regina Nzo, a leading figure in the African Natural Congress Women's League (Weekend Mail, 1990). Evaluating these statements in the context of a struggle to end apartheid sheds some light on the seeming insensitivity to women's needs. Family planning was a white-controlled program and thus a political target.

Several controversies surrounding the family planning program did not work to allay community suspicion. Depo-Provera, a long-lasting injectable contraceptive produced by the Upjohn company, was a major focus of criticism. A hormone-regulating drug that came to South Africa in the late 
1960s, Depo-Provera was received with enthusiasm by physicians (Tyler, 1968; Karstadt, 1970; Ferguson, 1974). The convenience of the injection as a contraceptive method that lasted for up to three months at a time was recognized by the administrators of the family planning program. Mobile-clinic schedules were organized around a three-month cycle to accommodate the term of the injection effects. Striking differences in contraceptive methoduse patterns by race quickly appeared. In the late 1980s, the injection was the method administered to more than 50 percent of all black users and 40 percent of colored users, while the pill and sterilization predominated among Indian and white users (Figure 5). However, the degree to which black and colored women, especially in rural areas, had a choice of methods presented to them was questionable (see also Chimere-Dan, 1993). With the Federal Drug Administration's ban on use of the drug in the United States, many

Figure 5 Contraceptive method use by race, South Africa, 1987-89

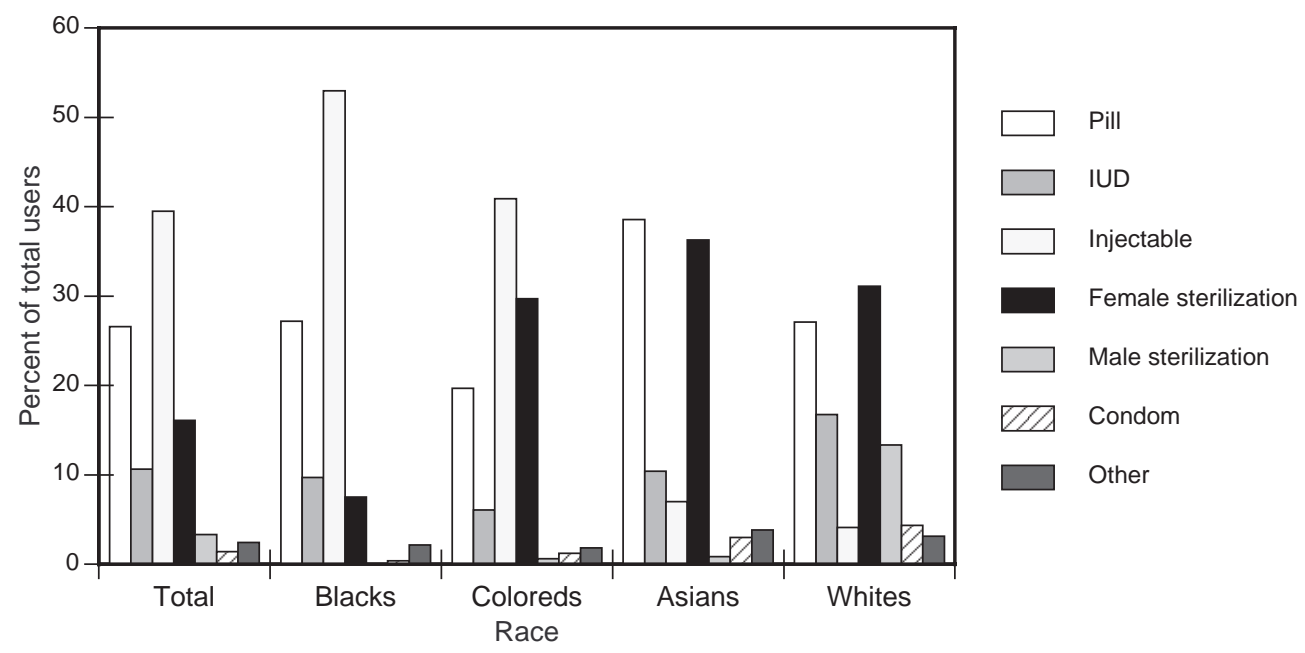

Source: Department of Health, Republic of South Africa, Annual Report, 1969-93. 
critics of the program accused the family planning program of subjecting nonwhite South African women to dangerous chemicals to achieve demographic objectives. Dr. Elin Hammar, a spokesperson for the Family Planning Association and a physician highly committed to and involved with nurses' training for the national program, stated in 1980 that the charges against Depo-Provera were grossly exaggerated, and that tests on monkeys and dogs that had resulted in their developing cancer, with some monkeys suffering shrinking uteruses, indicated low tolerance levels in the animals, and that, therefore, the results were not applicable to women. She denied that the injectable caused cancer of the cervix and stated that it was caused by the early onset of sexual activity or by activity with multiple sexual partners (SAIRR, 1980; see also Domisse, 1987). The controversy over DepoProvera, however, did not greatly alter the level of its use, in part because the national program did not cancel or limit the use of the method, but also because women preferred it. The injectable was a long-lasting form of fertility control that did not require consent or cooperation of a woman's partner (or her in-laws). For women who could not travel to clinics often and who feared the disapproval of their partners in their decision to avoid pregnancy, the injectable contraceptive was an ideal choice. Indeed, many women were willing to withstand uncomfortable side effects of the drug for the security of effective birth control (Gready et al., 1994; Kaufman, 1994).

The desire to avoid pregnancy often arose to facilitate employment. Employment opportunities were limited for black South African women and most positions were not amenable to the inconveniences of childbearing or child care. As one worker commented (Barrett et al., 1985: 142): "If someone knows you are pregnant, they will run to the nursing sister and tell her so 
that you are fired, and they know someone who can take your place." Contraceptive use became in many instances a pre-condition for hire and for continued employment. Though usually not made explicit, the Federation of South African Trade Unions (Women Workers) did bring one such agreement to the attention of the public (Barrett et al., 1985: 172).

Company, Ltd.

I, the undersigned, hereby declare that I am currently not pregnant. I further more agree that should I fall pregnant in the next twelve months, my service could be terminated immediately.

Signature

Pregnant women had no guarantee of a job after the birth of a child and were also susceptible to influx-control laws under which they would be judged unproductive and sent to the appropriate homeland. The fear of employment loss and the economic desperation that caring for another child stirred in women should not be underestimated. ${ }^{7}$ A manager described one outcome (Barrett et al., 1985: 142): "In a place where I worked before, a woman who was pregnant wrapped her stomach tightly so no one would know she was pregnant because she was afraid of losing her job. This made her abort." Another widespread practice known as the "fourth stage of labor," involved administering an injection immediately postpartum (Klugman, 1993; Stockton, 1995). The rationale for this practice is unknown, because women are usually anovulatory for several months after delivery. Nonetheless, nurses usually provided the injection as a matter of procedure. Permission from the 
patient was not sought generally, although sometimes the patient received the explanation that "the baby will be healthier" (Mamosadi, 1995). One young woman described her experience (Klugman, 1988: 102): "I used it after delivering my baby. I was taken there and given an injection without being told anything. They only took my blood pressure and gave me the next date for a checkup."

In spite of reported abuses in family planning service provision, community leaders by no means agreed about the disadvantages of family planning for blacks. Neto Motlana, a prominent civic leader in Soweto and personal physician to Nelson Mandela, has held strongly favorable opinions about family planning; Mandla Tshabalala, an influential professor at the University of Cape Town organized population forums and coordinated commissions concerned with population issues and has supported family planning even while criticizing the government program (Tshabalala, 1991); and Bishop Desmond Tutu has appeared in promotional advertisements for family planning (Brown, 1987). The 20 October 1990 issue of Cape Times reported results from a study on attitudes toward family planning that were indicative of the role community politics played in fertility control in general and gender relations in particular. The study showed that almost half of the black people in South Africa's major metropolitan areas believed that family planning was a government plot to reduce the black population. However, 59 percent of women felt that even if their men were opposed, they would practice birth control anyway. These women, although cognizant of the pressures, expectations, and opinions of important members of their communities, including their partners, felt strongly enough to disregard opinions contrary to their own (Cape Times, 1990). 


\section{Everyday Constraints on Reproductive Control for Black South African Women}

The last few decades have witnessed a dramatic decline in fertility levels in the black population of South Africa. Many African societies have prescribed behaviors that inhibit fertility, including prolonged breastfeeding and abstinence after childbirth, practices that still can be found throughout the continent (see, for example, Bongaarts et al., 1984). However, the presumption is that these behaviors are, by themselves, not sufficient to produce a sustained decline in fertility. In South Africa, the efforts of the vigorous and well-funded family planning program greatly facilitated the availability of modern contraceptives, but availability of effective methods is not enough. Couples must not only understand that they can control their fertility, but also that doing so benefits them. The structure of state-controlled labor patterns, residential policies, and the general incompatibility of women's employment and childbearing and rearing imparted a particular meaning to the phrase "benefits of smaller families." However, a benefit might also be compromised by the opinions and pressures of partners, elders, or in-laws. This section evaluates the constraints on fertility control from women's perspective and discusses how they have interpreted and acted upon having reproductive choice in their daily lives.

In 1993-94, the Women's Health Project (WHP) ${ }^{8}$ organized a series of focus groups to explore women's attitudes toward contraceptives, reproductive decisionmaking, and their experiences with family planning services (Gready et al., 1994). The following overview draws largely from WHP's focus-group materials; from oral history transcripts of the Killie Campbell Africana Library in Durban; from the Women in Phokeng oral history project 
of the Institute of Advanced Social Research, University of the Witwatersrand, Johannesburg; and from in-depth interviews conducted by the author in 1994 with African women throughout the former Transvaal province. ${ }^{9}$

The reasons women give for having children, and the reasons for having more children, demonstrate the range of reproductive control they have. Some women believe they have no place in making fertility decisions, others show an emergent self-confidence, and still others radiate an obvious sense of control and power over reproduction. The attitudes of men are central in accounting for these variations. Women talk a great deal about their partner's wanting children or not wanting children. The power of men in reproductive decisionmaking, however, is often discussed in terms of a mediating force. No matter what men want, the reality of life for an African woman in South Africa may well demand something else:

Oh men, they are still thinking in those old days, when, well, if God says you must have so many children, leave it to God. They seem to forget now that things are changing, on the other hand .... Here in the town they seem to forget that everything is money. If you have many children and you are getting pay in town, how are you going to support these children? ... So now the fathers, why don't they realise all these things? So that now let me have about two children, of which I'm going to be able to educate, and feed properly, such things. (kcav: 145, 1979). ${ }^{10}$

This woman, a leader in the Inkatha Women's League (at that time an organization to promote the culture of the Zulus), was most likely more educated and opinionated about fertility control than many other women. The 
sentiment was a common one, however, as another woman expressed (WHP, working class) $)^{11}$ : "We black people have a big problem because we are expected to be under the control of our husbands, they should control even the way we get children. What if his control is not correct?"

Beyond the immediate desire of their partners (discussed in more detail below), women's stated reasons for wanting or not wanting more children are indicative of the constraints they face. Most women who want more children give general reasons: "happiness," "joy," or an indication that having children sanctions their roles as women, that is, as mothers. Material reasons center on security in old age, a function of children in black families that is integral in a system that has limited state support for the elderly. ${ }^{12}$ Although parents rely on children to provide for them in old age, the relationship often spans several generations, a direct result of conditions for the employment of women in South Africa. In many cases, children are sent to their grandmothers while their mothers work, a pattern that has gone on for some time:

After [my husband's] death [in 1946] . . . I decided to leave for Johannesburg to go and work there. I had no house of my own and my children were still young, the only alternative which I had was to leave them behind with my mother-in-law and go work in Johannesburg. (Phokeng: 26) ${ }^{13}$

Grandmothers take care of their children's children, but the relationship is reciprocal; grandchildren care for their elders and act as a conduit for money and other goods: 
I am looking after my grandchildren. I am helping my children. When one bears a child she brings the child to live with me.

Do (the parents) pay you?

We did not agree on payment, but they gave me R20 per month. We did not say I am paying you for your job. It was a gift. (Phokeng: 17)

Are you not aware that it is through these grandchildren that I am able to get food from my child (the mother of these children)? Her husband would not have allowed her to send her mother food otherwise. (Phokeng: 22)

This next quote from a "grannie" not only expresses the important role children and grandchildren play, but acknowledges the hardship that a formal marriage might bring to a woman:

The way marriage has turned out to be. If your child is a lady teacher, let her get a child and bring it home. You will look after it. Tomorrow she gets another and brings it home. Because these children will look after you. Rather than have a husband who will fight every day. You won't have problems .... (Phokeng: 17)

Dependence on children in old age means having enough of them so that some will survive. Women in the former Transvaal province, in rural and urban communities alike, commonly expressed a desire to have many children because their mothers had so many children who died, or their sisters, or their neighbors. One woman described her concern to have many children because her mother was able to have so few; she wanted to "close 
the gap" (Kaufman, 1994). An awareness of the fragility of life with its implications for fertility was clear in the statements made by these women.

The most common reason given by women in the former Transvaal who did not want more children was economic circumstances, whereas younger respondents indicated that they wanted to delay childbearing until they completed their education. As the member of the Inkatha Women's League noted above, even in 1979, the cost of living was an immense problem. Women in the Transvaal repeatedly supported their fertility decisions on an economic basis: They had no money, their partners did not have jobs, they were already living with their parents. In short, children cost money that they didn't have. One woman in the former Natal province, describing this economic hardship, indicated that the child's father felt no compulsion to contribute economically:

In my case, what caused me to leave school was that I bore a child and had to go and find work. When I had the child I was not married, staying at home, and still attending school. Bringing up the child naturally involved considerable extra expense, but added to this was the fact the father and I had quarreled since he was not prepared to provide for it. (kcav:188, 1981)

Although this woman had to leave school, she described how she went through a series of jobs, and from each she learned skills that improved her condition of employment in the next job. Finally, she became a fully licensed driver, a rare event for an African woman at this time, which made possible a stable and relatively good income. Work for this woman was essential to provide for her child. ${ }^{14}$ Employment loss because of childbearing meant not 
only a loss of income for women, but increased expenditures to care for another child, further proscribing women's choices. This woman addressed this reality: "A girl can have the misfortune to have to leave home because she has borne a child. She leaves home to go and find work, then she will perhaps find a lover to take care of her and will often end up having a second child. And so her troubles continue unabated." By implicit contrast, she sees herself as a success: She did not need a lover to provide for her; she did not become pregnant again.

The role of men is central in reproductive decisionmaking dynamics. Sometimes, joint decisions are possible. Often, however, women feel that avoiding pregnancy is left to them alone in the face of unrealistic expectations of their partners: "[The men] say they want more children, they don't care, ten . . . they don't care ... . They will say . . I I want children . . . Y You see, they don't care whether [their wives] are suffering, you see, but they want children" (kcav:174, 1979). And some believe that a woman should take care of her own fertility: "Often women are the ones who control this because they are able to prevent pregnancy if they don't want to have children ... . Even if our men want to have children, if we are not prepared to do so, then there is nothing they can do" (WHP: informal settlement). Women of all ages have commented, either from personal experience or through observation, that increasingly, boyfriends are placing pressure on their girlfriends to bear them children.

I've been seeing my boyfriend for five years. Unfortunately, the first year we started seeing each other I didn't know anything about contraceptives ... so I fell pregnant and basically he' d been encouraging me to do so, but I didn't tell him I was pregnant. I had an abortion . . . . And 
he's been pestering me since... saying look, five years is just too much (not to have any children) (WHP, returnees).

Sometimes pressure is applied in the form of a promise of marriage; the woman need only prove her fertility first. Sometimes, and this condition seems more common, a man will ask his girlfriend for a child as proof of her love and commitment: "I have heard many women saying that if you want a man to stay with you for a long time, you must have a child with him. Have as many children as possible" (WHP, informal settlement). The use of contraceptives, conversely, implies that she does not trust him, or that she has other boyfriends. Pressures such as these are felt acutely by younger women, although they do not completely disappear with age (Parekh and de la Rey, 1995; Kaufman, 1994). In extreme cases, reproductive tension between partners results in physical abuse, especially because reproduction is considered central proof of masculinity (Motsei, 1995a). This portrayal of South African men, however, should be tempered by the fact that virtually all information available on men and their views about contraception is derived from reports from women. Smit and Venter (1991) found that in KwaZulu/Natal, 83 percent of women and 72 percent of men approved of contraception, although 65 percent of the women believed that men disapproved. As yet, little information exists on men's attitudes beyond this study. Klugman (1993) speculated that part of the ambivalence women feel toward contraception may be rooted less in its use per se than in their perception that their partners will disapprove.

Economic conditions, employment opportunities, and concern for the health and welfare of their families within the context of a racialized society motivated black South African women to use contraceptives in spite of im- 
mense pressure, real or assumed, to do otherwise. Although they may be applauded for their ability to seek out reproductive control under formidable conditions, the restricted choice women have had in South African society demands a critical approach to future issues of reproductive health.

\section{Population Policy and Reproductive Health in South AFricA, 1994 And Beyond}

The legacy of population policy under apartheid has left an ideological minefield and an administrative nightmare in its wake. Mirroring the anxiety of many whites toward a black-led government, the period prior to the 1994 elections saw an increase in popular news reports and public discussion on the consequences of rampant population growth (for example, Sunday Times, 1994; Weekend Star, 1994). Most of these reports were notable in that they lacked comment from major political parties. No political contender wished to commit himself or herself to a position on this sensitive issue. Indeed, the concerns with population abated after the elections because national attention shifted to the immediate issues of reorganization, integration, amnesty, housing, and land reform. Women's rights, reproductive health, and family planning were seen as politically intractable issues the new administration would rather avoid. Women's health services were barely mentioned in either the Reconstruction and Development Plan (ANC, 1994b), or the National Health Plan for South Africa (ANC, 1994a). However, women's groups have had a history of successful activism in South Africa (Seidman, 1993), and largely as a result of the efforts of a number of well-organized groups and highly motivated individuals, women's reproductive health concerns ultimately were pushed onto the agenda of the new 
administration. This process was aided considerably by the events leading up to and following the 1994 International Conference on Population and Development in Cairo. South Africa was re-entering the international community, and this event, following almost immediately after the elections, consumed a considerable amount of media coverage. Moreover, the agenda of reproductive health and reproductive rights, predominating themes of the conference, resonated with almost complete consonance with the framework South African groups had been pushing at home. The momentum of action was furthered by the United Nations Conference on Women in Beijing in 1995.

In spite of sustained efforts at the political level, the transformation of service delivery has been slower then many had hoped, and overcoming obstacles left from the previous regime will take time. However, racial politics surrounding family planning appear to be subsiding as services are integrated into the broader framework of reproductive health services (WHP, 1995 and 1996). Perhaps one of the most important changes since 1994, certainly a very controversial one, has been the legalization of abortion. The Termination of Pregnancy Act was passed in November 1996, and legal abortion services began on 1 February 1997. The issue of abortion remains contentious in South Africa, and the ability of advocacy groups to maintain its legal status, and the capacity of the Department of Health to ensure safe and accessible services, are unclear. Nonetheless, the effective organizing by various women's groups and health associations to lobby successfully for legal abortion in a conservative society suggests that South Africa has the capacity, underpinned by international support, to change legislative and organizational structures rapidly, even if implementation at the local level is much slower. 
Population policy issues have also moved forward, although their ties to the reproductive health agenda are tenuous, perhaps by design. An article on population control published in the Weekend Mail before the elections (October 5-11, 1990: 3) concluded with a statement from Desiree Daniels, an education officer for the Transport and General Workers Union: "I do think that a post-apartheid government should have a policy in this area, but it should come from the ground. If it emanates from the leadership it may have no effect on the ground." After the 1994 Cairo Conference, this is exactly what happened: A Green Paper outlining the population issues of the country solicited the public for opinions, thoughts, and ideas about whether South Africa should have a population policy, and if so, what form that population policy should take (Ministry for Welfare and Population Development, 1995). The draft of the White Paper on population policy, which incorporated the responses to the Green Paper, is currently under review (Republic of South Africa, 1996).

Most observers see the developments in both these areas, reproductive health and population policy, as positive signs of change even if they do not agree with the direction. Few, however, have addressed the continuing tension between promoting comprehensive reproductive health and reproductive rights from a feminist perspective and addressing the implications of demographic trends and population growth, issues which, in South Africa, have been framed historically in antifeminist terms. As Tsui (in Harkavy, 1995: 245) points out, "No exacting set of research findings exists to underwrite the expectations that improved reproductive and sexual health will prompt couples to exercise their reproductive choice in a manner that maintains fertility decline, and thereby slows population growth." Perhaps the 
creativity fostered by the enthusiasm for reproductive health in South Africa will produce a framework for a population policy that addresses demographic dynamics in a manner congruous with women's empowerment.

\section{Conclusions}

Caldwell and Caldwell (1993) may be correct that black South African fertility was not as low as the country's level of development would suggest. However, the declines achieved were remarkable both in absolute terms, fertility levels were lower than in any other country in sub-Saharan Africa by estimates of the late 1980s, and because they occurred in the midst of adverse conditions. This paper has sketched the context of that adversity in three different arenas: the national politics of population; the transformation of gender relations within a racially discriminatory society; and the proscriptions of everyday life for African women. The history of population issues, long rooted in racially based demographic trajectories, produced a climate of suspicion and hostility surrounding reproductive control, even before the national family planning program came into being. Services, once started, however, were, at best, unevenly received across communities, placing additional political constraints on accessibility. The decline in fertility for African women was no doubt aided considerably by the well-resourced national program. However, the larger context of racial domination in the form of homeland policies, labor migration, and discrimination placed a great deal of strain on the social and economic relationships of women, men, and their families, with direct implications for childbearing and rearing. Women came to manage their own fertility as they increasingly found themselves in precarious financial and social circumstances. In choosing to do so, however, 
they often had to endure community or familial censure, or seek services surreptitiously.

The constraints shaping women's desire or ability to have fewer children have not disappeared with the advent of democracy in South Africa; many of the dynamics outlined here continue to operate on fertility decisionmaking. Clearly, many questions about family-building in South Africa remain, including men's roles in fertility control, shifting patterns of adolescent childbearing, and intergenerational or other kinship structures of childrearing. Identifying those dynamics and the way they have come to shape the South African fertility decline will contribute greatly to a broader understanding of fertility dynamics in the region.

\section{Notes}

1. Under apartheid, all South Africans were officially categorized as white, colored (of mixed heritage), Indian (or Asian) or black (or African). These classifications were legally sanctioned by the South African government and have been used throughout official statistics and much research on South Africa. Because of this and because persons were indeed treated in a particular way socially, legally, and economically on the basis of their racial status, these terms are also used in this manuscript. I use "African" and "black" interchangeably to refer to the indigenous population.

2. Family planning measures are taken from annual reports of the Department of Health. Contraceptive use rates and total fertility rates are taken from the 1987-89 South African Demographic and Health Sur- 
vey, conducted by the South African Human Sciences Research Council. See Kaufman (1997) for an assessment of the quality of these data.

3. In fact, 13 percent represented a slight improvement over the 10 percent set aside in the 1913 Natives Land Act. To "compensate" for the increase in African land, the Representation of Natives Act of 1936 stripped the franchise from Africans in the Cape, the last vestige of limited African voting rights.

4. Four homelands, Transkei, Bophuthatswana, Venda, and Ciskei, eventually became so-called independent states with sovereign rights. The remaining six, KwaZulu, KwaNdebele, QwaQwa, KaNgwane, Gazankulu, and Lebowa, refused to opt for "independence" and remained a part of the Republic of South Africa, but with some selfgoverning rights within their borders. Political rights were conferred to the "homelands" under the oversight of the South African government.

5. Census data are of dubious quality in South Africa. The information on these graphs are used to convey trends and not exact estimates.

6. Pass laws were abolished in 1986.

7. These factors contributed significantly to a high estimated rate of illegal abortion. Abortions had been illegal in South Africa except in narrowly defined circumstances. Approximately 36,000 women suffering from the effects of an illegal abortion are treated in hospitals annually, and at least 100 women die from complications of abortions 
each year (Walker, 1994?). On 12 November 1996, the Choice on Termination of Pregnancy Act was signed into law which provides for abortion on request up to the twelfth week of pregnancy and conditionally thereafter (The Star, 1996).

8. The Women's Health Project is a nongovernmental organization affiliated with the Centre for Health Policy, University of Witwatersrand, Johannesburg.

9. These interviews were conducted in a variety of locations and settings including fixed and mobile clinic sites, white-owned farms, townships, and city centers in what are now Gauteng, Northern, and Mpumalanga provinces. The sample was not selected to be representative of the larger population, but to capture a wide variety of perspectives and opinions on fertility issues among black South African women.

10. Refers to tape number and year of interview of the oral history transcript in the Killie Campbell Africana collection (kcav).

11. Refers to Women's Health Project focus-group interviews and group context.

12. Pensions play a crucial role in South African society, especially among Africans. Though the income is meager, increasing poverty has given rise to situations in which a grandmother's pension provides the sole income for an entire household.

13. Refers to interview number of the Women of Phokeng oral history project. 
14. In contrast to this case, and unlike many other settings in sub-Saharan Africa, adolescent childbirth does not necessarily result in permanent school-leaving. Girls in South Africa, especially in urban areas, often continue their education after giving birth (Preston-Whyte et al., 1990; Parekh and de la Rey, 1995).

\section{References}

African National Congress (ANC). 1994a. A National Health Plan for South Africa. Johannesburg: ANC.

-__. 1994b. The Reconstruction and Development Programme. Johannesburg: Umanyano Press.

Barrett, Jane, Aneene Dawber, Barbara Klugman, Ingrid Obery, Jennifer Shindler, and Joanne Yawitch. 1985. Vukani Makhosikazi: South African Women Speak. London: Catholic Institute for International Relations.

Bongaarts, John, Odile Frank, and Ron Lesthaeghe. 1984. "The Proximate Determinants of Fertility in Sub-Saharan Africa." Population and Development Review 10 (3): 511-537.

Borgstrom, Georg. 1965. The Hungry Planet: The Modern World at the Edge of Famine. New York: Macmillan.

Bozzoli, Belinda. 1983. "Marxism, Feminism and South African Studies." Journal of Southern African Studies 9 (2): 139-171.

Bozzoli, Belinda and Mmantho Nkotsoe. 1991. Women of Phokeng: Consciousness, Life Strategy and Migrancy in South Africa, 1900-1983. Portsmouth, NH: Heinemann.

Brown, Barbara B. 1983. "The Political Economy of Population Policy in South Africa." In Margaret I. Aguwa (ed.), Women, Health, and International 
Development. East Lansing: Office of Women in International Development and African Studies Center, Michigan State University. (Proceedings of the Conference on Women, Health, and International Development. Michigan State University, East Lansing. 22-23 October 1982.)

. 1987. "Facing the 'Black Peril': The Politics of Population Control in South Africa." Journal of Southern African Studies 13 (3): 256-273.

Caldwell, John C. 1970. "Family Planning Programs and Official Policy Decisions in Southern Africa." Unpublished report to the Population Council.

Caldwell, John and Pat Caldwell. 1993. "The South African Fertility Decline." Population and Development Review 19 (2): 225-262.

Cape Times. 1985. "Port Elizabeth women urged to have babies." 19 July: 2. 1990. "Birth control a "government plot." 20 October: 8.

Central Statistical Service. 1993. South African Statistics. Pretoria: Government Printers.

Chimere-Dan, Orieji. 1993. "Population Policy in South Africa." Studies in Family Planning 24 (1): 31-39.

Cock, Jacklyn. 1988. "Trapped workers: The case of domestic servants in South Africa." In Sharon B. Stichter and Jane L. Parpart (eds.), Patriarchy and Class: African Women in the Home and the Workforce. Boulder, CO: Westview Press.

Department of Health, Republic of South Africa. Annual Reports for years 1968-93. Pretoria: Government Printers.

Domisse, J. "Depo-provera: The controversial contraceptive." South African Medical Journal (August): 232.

du Plessis, G.E., B.E. Hofmeyer, and W.P. Mostert. 1991. "Fertility Differentials in South Africa, 1987-89." In "Memorandum to the Director- 
General of the Department of National Health and Population Development." Pretoria: Human Sciences Research Council.

Dubow, Saul. 1987. "Race, Civilization, and Culture: The Elaboration of Segregationist Discourse in the Inter-War Years." In Shula Marks and Stanley Trapido (eds.) The Politics of Race, Class and Nationalism in Twentieth-Century South Africa. London: Longman Group.

Ehrlich, Paul R. 1968. The Population Bomb. New York: Ballantine Books. Ferguson, D. 1974. "Family Planning in a Predominantly Non-White Rural South African Community." South African Medical Journal (June): $1,163-1,164$.

Gready, Meg, Barbara Klugman, Emelda Boikanyo, Helen Rees, and Makhosazana Xaba. 1994. "When Is Yes Really Yes?: The Experiences of Contraception and Contraceptive Services Amongst Groups of South African Women." Johannesburg: Women's Health Project.

Hansard's. Debates of Parliament (also Debates of the House of Assembly [Hansard]), various years 1933-90. Republic of South Africa.

Harkavy, Oscar. 1995. Curbing Population Growth: An Insider's Perspective on the Population Movement. New York: Plenum.

James, Deborah. 1988. "Land Shortage and Inheritance in a Lebowa Village." Social Dynamics 14: 36-51.

Karstadt, B. "Injectable Long-acting Progestogens for Contraception." South African Medical Journal (April): 480-481.

Kaufman, Carol E. 1994. "Fertility and Contraceptive Use in the Transvaal." Private data collection, unpublished.

1996. "The Politics and Practice of Reproductive Control in South Africa: A Multilevel Analysis of Fertility and Contraceptive Use." Ann Arbor: Department of Sociology, University of Michigan. Unpublished doctoral dissertation. 
. 1997. "1987-89 South African Demographic and Health Survey: Methodology and Data Quality." Population Studies Center Research Reports, no. 97-395. Ann Arbor: University of Michigan.

Killie Campbell Oral History Project (kcav). 1979-82. Killie Campbell Africana Library, Durban.

Klugman, Barbara. 1988. Decisionmaking on Contraception Amongst a Sample of Urban African Working Women. Department of Sociology, University of the Witwatersrand, Johannesburg, South Africa. Unpublished master's thesis.

- 1991. "Population Policy in South Africa: A Critical Perspective." Development Southern Africa 8 (1): 19-34.

1993. "Feminism, Population Planning and the Provision of Contraceptives in South Africa." Paper presented at the Institute on Health and Demography in sub-Saharan Africa, Institute for Advanced Study and Research in the African Humanities, Northern University, Evanston, Illinois, 14 January.

1994. “A Brief History and Reflection on Population Policy in South Africa - Where to from Here?" Draft of discussion paper of the Development Bank of Southern Africa.

Longmore, Laura. 1959. The Dispossessed: A Study of the Sex-Life of Bantu Women in Urban Areas in and Around Johannesburg. London: Jonathon Cape.

Lucas, David. 1992. "Fertility and Family Planning in Southern and Central Africa." Studies in Family Planning 23 (3): 145-158.

Mamosadi, Pascalis Salome. 1995. Registered nurse in family planning. Personal communication, Johannesburg, 6 October.

Mason, Karen Oppenheim. 1987. “The Impact of Women's Social Position on Fertility in Developing Countries." Sociological Forum 2 (4): 718-745. 
Ministry for Welfare and Population Development. 1995. Green Paper for Public Discussion: Population Policy for South Africa. Pretoria: Promedia.

Moodie, T. Dunbar and Vivienne Ndatshe. 1992. "Town Women and Country Wives: Migrant Labour, Family Politics and Housing Preference at Vaal Reefs Mine." Labour, Capital and Society 25 (1): 116-132.

Mostert, W.P. 1972. Die Gesinsbouproses by Bantoes in die Metropolitaanse Gebied van Durban. Verslag nr. S-16. Pretoria: Raad vir Geesteswetenskaplike Navorsing.

— 1990. "Recent Trends in Fertility in South Africa." In W.P. Mostert and J.M. Lotter (eds), South Africa's Demographic Future. Pretoria: Human Sciences Research Council.

Mostert, W.P. and G.E. du Plessis. 1990. "Contraceptive Use in South Africa: 1987-1989." In Memorandum to the Director General of the Department of National Health and Population Development. Pretoria: Human Sciences Research Council.

Mostert, W.P. and J.L. du Plessis. 1972. Die Gesinsbouproses by Bantoes in die Munisipale Gebied van Pretoria. Verslag nr. S-17. Pretoria: Raad vir Geesteswetenskaplike Navorsing.

Mostert, W.P. and J. Engelbrecht. 1972. Die Gesinsbouproses by Bantoes in die Metropolitaanse Gebied van Kaapstad. Verslag nr. S-15. Pretoria: Raad vir Geesteswetenskaplike Navorsing.

Mostert, W.P. and I.J. van Eeden. 1972. Die Gesinsbouproses by Bantoes in die Metropolitaanse Gebied van Johannesburg: Soweto. Verslag nr. S18. Pretoria: Raad vir Geesteswetenskaplike Navorsing.

Motsei, Mmatshilo. 1995a. Consultant for the Development Bank of South Africa and for the Government of National Unity on women's roles; Coordinator, Agisanang Domestic Abuse Prevention and Training (Alexandra Clinic). Personal communication, Midrand, October 19. 
—. 1995b. "Draft Policy for Women's Empowerment." Unpublished.

Parekh, Angina and Cheryl de la Rey. 1995. "Intragroup Accounts of Teenage Motherhood in a Peri-Urban Area in KwaZulu Natal, South Africa." Unpublished.

Platzky, Laurine and Cherryl Walker. 1985. The Surplus People: Forced Removals in South Africa. Johannesburg: Ravan Press.

Posel, Deborah. 1991. The Making of Apartheid, 1948-1961: Conflict and Compromise. Oxford: Clarendon Press.

Preston-Whyte, E.M. 1990. "Qualitative Perspectives on Fertility Trends Among African Teenagers." In W.P. Mostert and J.M. Lötter (eds), South Africa's Demographic Future. Pretoria: Human Science Research Council.

Preston-Whyte, E.M., Maria Zondi, Gladys Mavundla, and Hilda Gumede. 1990. "Teenage Pregnancy, Whose Problem? Realities and Prospects for Action in KwaZulu/Natal." Southern African Journal of Demography 3: 11-20.

Republic of South Africa. 1983. Report of the Science Committee of the President's Council on Demographic Trends in South Africa. Cape Town: Government Printers.

- 1996. Draft White Paper for a Population Policy. Government Gazette vol. 376, no. 17529. Pretoria: Government Printers.

Romero-Daza, Nancy. 1994. "Multiple Sexual Partners, Migrant Labor, and the Makings for an Epidemic: Knowledge and Beliefs about AIDS Among Women in Highland Lesotho." Human Organization 53 (2): 192-205.

Sadie, J.L. 1970. "The Costs of Population Growth in South Africa." South African Journal of Economics 40 (2): 107-118. 
Seidman, Gay W. 1993. “ 'No Freedom without the Women': Mobilization and Gender in South Africa, 1970-1992." In Signs: Journal of Women in Culture and Society 18 (2): 291-320.

Sharp, John and Andrew Spiegel. 1990. "Women and Wages: Gender and the Control of Income in Farm and Bantustan Households." Journal of Southern African Studies 16 (3): 527-549.

Sharpless, John. 1994. "World Population Growth, Family Planning and American Foreign Policy." Working Paper Series, No. 15. Ann Arbor: Advanced Study Center, International Institute, University of Michigan.

Smit, Jennifer A and Wenonah M. Venter. 1991. Attitudes to Family Planning in Natal/KwaZulu. Volume 1: Attitudes to Family Planning, Family Size and the Delivery of Family Planning Services. Durban: Planned Parenthood Research Unit, University of Durban-Westville.

South African Institute of Race Relations (SAIRR). Annual Survey. Various years (1970-94). Johannesburg: SAIRR.

South African Demographic and Health Survey. 1987-89. Pretoria: Human Sciences Research Council.

South African Medical Journal. 1970. "Population Explosion." Editorial. July 18: 830 .

The Star. 1986. "Sterilization will be 'vital' for South Africa." 18 March: 5.

— 1996. "The Choice on Termination of Pregnancy Act." 28 November: 50 .

Stockton, Natalie Jessie. 1990. "The Nurse in the National Family Planning Programme of South Africa." Department of Nursing Science, Rand Afrikaans University, South Africa. Unpublished Master's thesis.

- 1995. Former Director of Family Planning Services. Personal communication, Pretoria, October 24, 27. 
Sunday Times. 1994. "South Africa could become ungovernable." (advertisement) 6 March.

Tshabalala, Mandla. 1991. "Perceptions, Values and Attitudes of Black South Africans on Rapid Population Growth." In Jordaan, Johannes, Рориlation Growth - Our Time Bomb: The Solution to South Africa's Population Problem. Pretoria: J.L. van Shaik.

Tyler, Edward T. 1968. "Current Studies in Contraception: The Use of a Long-Acting Progestogen by Injection." South African Medical Journal (March): 257-259.

van Rensburg, Ena. 1994. International Liaison and Program Advisory Services of the Population and Development Programme. Personal communication, Pretoria, 8 March.

van Rensburg, Nic J. 1972. Population Explosion in Southern Africa. Pretoria: J.L. van Shaik.

van Zuydam, Jacques. 1994. "Transforming the Population Development Programme: The case of the Eastern Cape region." Paper prepared for the First Annual Conference of the South African Sociological Association, University of Natal, Pietermaritzburg, 3-4 July.

Walker, Cherryl. 1990. "Gender and the Development of the Migrant Labour System c. 1850-1930: An Overview." In Cherryl Walker (ed.), Women and Gender in Southern Africa to 1945. Cape Town: David Philip.

Walker, Elizabeth. 1994(?). "Abortion: Some Insights into Power and Patriarchy." Occasional Paper No. 3. Johannesburg: Department of Sociology, University of the Witwatersrand.

Weekend Mail. 1990. "Population growth: State control or free love?" 5-11 October: 3,5 .

Weekend Post. 1986. "Men step into 'female role' as family planners." 8 August. 
Weekend Star. 1994. "Storm blows over.”19-20 March.

Wilson, Francis and Mamphela Ramphele. 1989. Uprooting Poverty: The South African Challenge. Cape Town: David Philip.

Wolpe, Harold. 1972. "Capitalism and Cheap Labour-Power in South Africa: From Segregation to Apartheid." Economy and Society 1 (4): 42556.

Women's Health Project Focus-group Transcripts. 1993-94. Johannesburg: University of the Witwatersrand, Women's Health Project, Centre for Health Policy.

Women of Phokeng Oral History Project. 1981-1984. Johannesburg: University of the Witwatersrand, Institute of Advanced Social Research.

World Health Organization (WHO). 1983. Apartheid and Health. Geneva: WHO.

\section{Acknowledgments}

This research was supported by an International Predissertation Fellowship from the Social Science Research Council and the American Council of Learned Societies with funds provided by the Ford Foundation. Further assistance from the Center for Afroamerican and African Studies Research Project, "African Peoples in the Industrial Age," with support from the International Institute, University of Michigan, is gratefully acknowledged. The author is grateful to Cynthia Lloyd for her helpful comments on an earlier draft of this paper. 


\title{
POLICY RESEARCH DIVISION WORKING PAPERS
}

\author{
Recent Back Issues
}

1995

* 70 Sajeda Amin, John Cleland, James F. Phillips, and Gholam Mostafa Kamal, "Socioeconomic change and the demand for children in rural Bangladesh."

71 John Bongaarts, "The role of family planning programs in contemporary fertility transitions."

72 Geoffrey McNicoll, "On population growth and revisionism: Further questions."

73 James F. Phillips, Mian Bazle Hossain, and Mary Arends-Kuenning, "The longterm demographic role of communitybased family planning in rural Bangladesh."

74 Cynthia B. Lloyd, "Household structure and poverty: What are the connections?"

75 Sajeda Amin, "The poverty-purdah trap in rural Bangladesh: Implications for women's roles in the family."

76 Martin Brockerhoff, "Child mortality in East Africa: The impact of preventive health care."
77 Thomas K. LeGrand and James F. Phillips, "The effect of fertility reductions on infant and child mortality: Evidence from Matlab in rural Bangladesh."

78 Cynthia B. Lloyd and Ann K. Blanc, "Children's schooling in sub-Saharan Africa: The role of fathers, mothers, and others."

79 Geoffrey McNicoll, "Demography in the unmaking of civil society."

80 John Bongaarts, "Global trends in AIDS mortality."

81 Barbara Mensch, Mary ArendsKuenning, Anrudh Jain, and María Rosa Garate, "Meeting reproductive goals: The impact of the quality of family planning services on unintended pregnancy in Peru."

82 Mark Montgomery, Aka Kouamé, and Raylynn Oliver, "The tradeoff between the number of children and their schooling: Evidence from Côte d'Ivoire and Ghana." 
83 Sajeda Amin, Ian Diamond, and Fiona Steele, "Contraception and religious practice in Bangladesh."

84 John B. Casterline, Aurora E. Perez, and Ann E. Biddlecom, "Factors underlying unmet need for family planning in the Philippines."

85 Geoffrey McNicoll, "Governance of fertility transition: Regularity and duress."

86 John Bongaarts, "Population pressure and the food supply system in the developing world."

87 Sajeda Amin, "Family structure and change in rural Bangladesh."

88 John Bongaarts and Susan Cotts Watkins, "Social interactions and contemporary fertility transitions."
89 Cynthia B. Lloyd and Mark R. Montgomery, "The consequences of unintended fertility for investments in children: Conceptual and methodological issues."

* 90 Zeba Sathar and Sonalde Desai, "Work patterns in rural Pakistan: Intersections between gender, family, and class."

* 91 Mark R. Montgomery, "Learning and lags in mortality perceptions."

92 Ann E. Biddlecom, John B. Casterline, and Aurora E. Perez, "Men's and women's views of contraception."
93 James F. Phillips, Fred N. Binka, Martin Adjuik, Alex Nazzar, and Kubaze Frank Adazu, "The determinants of contraceptive innovation: A case-control study of family planning acceptance in a traditional African society."

94 John Bongaarts and Sajeda Amin, "Prospects for fertility decline and implications for population growth in South Asia."

95 Barbara S. Mensch and Cynthia B. Lloyd, "Gender differences in the schooling experiences of adolescents in low-income countries: The case of Kenya."

96 Martin Brockerhoff and Ellen Brennan, "The poverty of cities in the developing world."

97 Carol E. Kaufman, "Reproductive control in South Africa."

* No longer available 